\title{
Sustainability assessment of urban infrastructures
}

DOI:

10.1108/9781800436367

\section{Document Version}

Accepted author manuscript

Link to publication record in Manchester Research Explorer

\section{Citation for published version (APA):}

Barker, A., Felliu, E., Garcia-Blanco, G., Kwiacinska, K., \& Pedrola, B. (2021). Sustainability assessment of urban infrastructures. In E. Crocci, \& B. Lucchitta (Eds.), Nature Based Solutions for More Sustainable Cities: A Framework Approach for Planning and Evaluation (pp. 97-110). Emerald Publishing Limited. https://doi.org/10.1108/9781800436367

\section{Published in:}

Nature Based Solutions for More Sustainable Cities

\section{Citing this paper}

Please note that where the full-text provided on Manchester Research Explorer is the Author Accepted Manuscript or Proof version this may differ from the final Published version. If citing, it is advised that you check and use the publisher's definitive version.

\section{General rights}

Copyright and moral rights for the publications made accessible in the Research Explorer are retained by the authors and/or other copyright owners and it is a condition of accessing publications that users recognise and abide by the legal requirements associated with these rights.

\section{Takedown policy}

If you believe that this document breaches copyright please refer to the University of Manchester's Takedown Procedures [http://man.ac.uk/04Y6Bo] or contact uml.scholarlycommunications@manchester.ac.uk providing relevant details, so we can investigate your claim.

\section{OPEN ACCESS}


NATURE-BASED SOLUTIONS FOR MORE SUSTAINABLE CITIES - A FRAMEWORK APPROACH FOR

PLANNING AND EVALUATION

2.3 SUSTAINABILITY ASSESSMENT OF URBAN INFRASTRUCTURES

Adam Barker, Associate Professor/Senior Lecturer at University of Manchester UK adam.barker@manchester.ac.uk

Efren Feliú, Climate Change Manager at the TECNALIA Research \& Innovation Spain efren.feliu@tecnalia.com

Gemma Garcia- Blanco, Senior researcher at the TECNALIA Research \& Innovation Spain gemma.garcia@tecnalia.com

Kornelia Kwiecinska, Senior researcher at Wroclaw University of Environmental and Life Sciences Poland - kornelia.kwiecinska@upwr.edu.pl

Blanca Pedrola, architect at Bipolaire Arquitectos Spain - blancapedrola@bipolaire.es

\section{Author biography}

Adam Barker, Associate Professor/Senior Lecturer at University of Manchester UK

Research experience in environmental assessment, spatial planning and climate change adaptation. Currently lectures on the MSc in Environmental Impact Assessment and Management (EIAM) in the Department of Planning and Environmental Management. Chartered Member of the Royal Town Planning Institute (MRTPI) and Academic Member of the Landscape Institute (AMLI).

Efren Feliú, Climate Change Manager at the TECNALIA Research \& Innovation Spain

Building Engineering Degree as well as different postgraduates including spatial planning and territorial development. Relevant professional background in consultancy and capacity development for public administrations and utilities, specially focused on the fields of local sustainability, spatial planning, climate adaptation and resilience. Member of the Covenant of Mayors Practitioners Group (advisory board).

Gemma Garcia- Blanco, Senior researcher at the TECNALIA Research \& Innovation Spain

BA in Geography (University of Oviedo) and MSc in Environmental Sciences (University of East Anglia, UK). Research experience on the fields of spatial and urban planning, sustainability, environmental assessment, climate adaptation and resilience, strengthening initiatives for public administrations. Research interests: Climate Change Adaptation, Nature-based Solutions and Innovative Planning.

Kornelia Kwiecinska, Senior researcher at Wroclaw University of Environmental and Life Sciences Poland MSc in Chemistry and PhD in Environmental Engineering. Member of Environmental Risk Management and Ecosystem Monitoring Centre team at Wrocław University of Environmental and Life Sciences. Research experience in environmental impact assessment, climate change mitigation and adaptation, nature-based solutions, green infrastructure (i.a. green roofs, vegetative environmental buffers) in environmental engineering.

Blanca Pedrola, architect at Bipolaire Arquitectos SpainArchitect and Urban Planner (Universidad Politécnica de Valencia) and Master in Architectural Engineer (Civil Engineering School, Illinois Institute of Technology, USA). Relevant professional background in sustainable urban transformation projects, 


\begin{abstract}
The 'renaturing' of cities through an increased emphasis on the use of Nature Based Solutions (NBS) potentially offers urban areas the opportunity to deliver multiple environmental and socio-economic benefits. In particular, approaches linked to NBS can limit the degree of climate exposure and vulnerability impacting upon urban infrastructures. The success of NBS in addressing climate change pressures will require an improved understanding of the characteristics of environmental risk and the ability to evaluate alternate adaptive pathways. In response, this chapter explores those components which are central to effective urban infrastructure assessment and considers how they may assist in formulation of infrastructure strategy.

We stress the need for an approach which is both, scenario focused and fully integrated within existing spatial planning frameworks. Here we draw specific attention to the utility of Strategic Environmental Assessment (SEA) in both embedding environmental evaluation within mainstream spatial planning and providing the basis for the comparative evaluation of alternatives. We also argue for an approach which recognizes areas of complementary interaction between 'grey infrastructure' (whether existing or proposed) and approaches linked to NBS. In order to highlight examples of potential development responses, we draw on best-practice case study examples from the EU funded GROW GREEN project.
\end{abstract}

\title{
Keywords
}

1. NBS sustainability

2. Infrastructures assessment

3. Urban infrastructures

4. Environmental impacts

5. Urban planning

6. Urban challanges 


\subsubsection{A Renaturing of cities}

Although sustainability has emerged as a dominant paradigm for urban development, cities are complex and dynamic entities which have evolved over time to satisfy a range of changing spatial agendas. In Europe, this has typically seen cities configured to favor industrial advancement, housing supply, increased transportation opportunity and amenity space. Consequently, urban infrastructures, along with the services they provide, are not necessarily responsive to current sustainability challenges. Most have been developed utilizing standardized urbanization models (Lafortezza and Sanesi, 2019) which have prioritized the provision of 'grey infrastructure'. This has been accompanied by an overriding supply driven ethos based on reliable and cost-effective service provision. Demands for increased supply have usually been met with infrastructure extension and upgrade rather than socio-economic and environmental reform.

Traditional urban infrastructures do have physical functions that include transport, water management (water storage and supply, hydropower production, flood prevention), waste management (sewage, urban waste, industrial waste), power generation, industrial activity or those associated with urban settlements. These infrastructures are the basis for the provision of a series of "goods and services" absolutely necessary for our way of life. However, grey infrastructure development does also have negative consequences and a direct impact on the elimination or substantial modification of ecosystems through artificialization of land, river channels and the coastal strip, in addition to other indirect effects such as fragmentation of associated habitats, or disruption of the dynamics of ecosystems at higher spatial scales such as basin or landscape.

The emphasis on 'business as usual', as it has been previously described, has left urban areas particularly vulnerable to the temporal and spatial threats resulting from climate change. In response, there has been a call amongst scholars and practitioners alike to work toward the renaturing of cities. This approach seeks to maximize the provision of ecosystem services (ES) in order to improve the alignment between urban development and sustainability. As part of this approach, significant emphasis is placed in the ability to deliver low environmental impacts whilst ensuring the delivery of social and economic gains. Renaturing of cities by means of Nature based Solutions (NBS) potentially provide the urban environment with multiple benefits. The biophysical characteristics of NBS can improve the quality of the urban environment through, inter alia, biodiversity enhancement, pollution filtration, noise absorption, rainwater retention, oxygen production and improved thermal efficiency (Enzi et al 2017). Several of these benefits can be enhanced by the additional functionality afforded by blue infrastructure (particularly, rainwater retention, temperature control and biodiversity provision). Together these infrastructure provisions can also bring distinct socio- economic benefits. These can vary from the alleviation of urban stress through the ability to reconnect to nature to improved investment opportunities brought by enhanced liveability.

As an example, we have seen how the COVID 19 pandemic has stressed the importance of green and blue spaces for enhancing social reliance, which in turn has facilitated certain mental and physical health benefits. Urban green spaces, such as parks, playgrounds, and residential greenery, can promote mental and physical health, and reduce morbidity and mortality in urban residents by providing psychological relaxation and stress alleviation, stimulating social cohesion, supporting physical activity, and reducing 
NATURE-BASED SOLUTIONS FOR MORE SUSTAINABLE CITIES - A FRAMEWORK APPROACH FOR PLANNING AND EVALUATION

exposure to air pollutants, noise and excessive heat (WHO, 2016). Ensuring access to nature for all citizens should thus be a fundamental strategy of cities.

\subsubsection{Sustainable infrastructures to inform planning decisions in a global change}

Regarding urban infrastructures, the future scenario of increased urban population anticipates that urbanization has huge investment implications for infrastructure in the next decades. Adding to that the current situation of climate emergency, integrated solutions are needed to create resilient cities, where environmental, social and economic aspects are included.

The transition towards more sustainable and resilient forms of urban infrastructure is likely to require the development of principles rooted in both adaptive management and an improved understanding of vulnerability and acceptance to change. Whilst the severity of natural hazards cannot be reduced, it is possible, through environmentally sensitive solutions, to reduce the degree of exposure and vulnerability impacting upon urban infrastructures. Addressing these elements of environmental risk will, in turn, require ways for identifying and understanding the drivers of change and a commitment to changing traditional development pathways. The extent to which this transition towards sustainability and resilient urban infrastructures can be achieved will be dependent upon an ability to meet a series of transition requirements.

Of particular importance is the need to enhance our understanding of socio-ecological systems and how they operate in urban areas. Feliu and Garcia (2020) have argued that the ability to develop responsive climate change adaptation strategies will require an improved appreciation of the manner in which ES adaptation and green infrastructure provision can be incorporated within NBS.

Therefore, it is very important to dedicate knowledge, efforts and resources to understand and assess the effects of urbanization and of climate change in each territorial context to determine its vulnerability and to design adaptation strategies which in term could better inform planning decisions. These adaptation strategies will be aimed at minimizing greenhouse gases (GHG) emissions and at reducing the vulnerability of the territory and should include definitions of strategic alternatives in relation to critical urban infrastructures for energy security and distribution; transport networks and services; ES; management of water resources, and strengthening economic systems and the most vulnerable social groups.

In this context, spatial and urban planning are seen as enabling disciplines for territorial and urban development that articulate the deployment of other public policies affecting the spatial organization and governance of land. Spatial and urban planning instruments could be enablers or determinants for successful implementation of sustainable principles (Feliu and Garcia, 2020).

Understanding socio-ecological systems and NBS is key towards sustainability because:

- identifying and quantifying the benefits and challenges of green interventions is important for strategic planning and development of European regions and cities, providing options which link 
environmental, social and economic benefits within a single space, which may not be provided by traditional grey infrastructure.

- the outcomes of planning decisions can be improved using existing knowledge and data (about benefits and potential side effects) in order to quantify the multiple benefits and costs of implementing NBS.

- context matters in NBS, particularly the type of infrastructure and its spatial configuration. Understanding this context improves quantification of the benefits and negative impacts, improving accuracy of planning decisions.

\subsubsection{But... How do we assess sustainability?}

From the perspective of a policy led planning system, substantial efforts have been done in the assessment of urban infrastructures.

Benchmarking alternative planning scenarios is conceived as a best practice. The implementation of sustainability principles in urban infrastructures requires, on the one hand, to develop, through scientific-technical research and benchmarking in the disciplines involved, a "knowledge base" that allows us to objectively evaluate the different alternatives, from a comprehensive approach that incorporates the relationships between the three components of sustainability. And on the other hand, it requires defining the particularities of the context. That is, define the social, economic, ecologicalenvironmental aspects and territory in which said evaluation will be applied, based on the preparation of a shared vision in terms of sustainability through the participation of all agents and citizens. This vision would establish the general criteria for the sustainable management of the territory, which would later be translated into the different plans, programs, etc., as well as commitments to contribute from the local management to the global sustainability of the planet.

Scenarios are an effective way to deal with the uncertainty inherent to complex systems and lack of data. NBS and ES could be used to generate alternative planning scenarios, benchmark and decide which ones have less significant impacts and maximize the NBS network and provision of ES.

Therefore, the questions that we must ask ourselves are:

- $\quad$ should the supply of infrastructures be increased to respond to a "growing" demand for these goods / services? Are grey infrastructures more efficient in the provision of these goods and services that the natural systems themselves properly managed?

- what are the goods / services that we stop perceiving as a result of the infrastructure development and what is the value of these assets? These goods that we stop perceiving, can they be supplied by technology? At what price? and what are the minimum thresholds?

- how to achieve greater complementarity between green and grey solutions in the supply of all "goods and services" necessary so that the considerations are minimized, and win-win solutions prevail? 
The GROWGREEN project has elaborated a compendium (GrowGreen, 2020) of green and grey solutions with an index for all available NBS that address certain climate and water problems.

The use of alternatives and scenarios within strategic decision making, could be to some extent handled via the application of the Strategic Environmental Assessment (SEA), based on Directive 2014/52/EU of the European Parliament and of the Council of 16 April 2014. The SEA is an administrative procedure and an instrument that accompanies the approval and adoption of strategies, plans and programs with a potential environmental impact. The SEA aims to provide a high level of protection of the environment and to contribute to the integration of environmental considerations into the preparation and adoption of all strategies, plans and programs. It is applicable at various planning scales (i.e. national, regional, local).

In general, the integration of NBS into spatial planning through the SEA has followed two approaches (GRETA, 2019):

- $\quad$ NBS considered as a distinct sector of policy, spatial planning and urbanism (at the same level as housing, land use and transport). In this approach, NBS is seen primarily as an 'object' of planning (rather than a result of planning) - to be applied to existing protected areas such as the Natura2000 network.

- NBS as a 'product' or result of an integrated approach to planning, where development needs and protective demands are reconciled into the same spatial plan - applicable at different levels (regional, local/city). NBS provides an integrative framework that supports the comprehensive assessment of ecological processes, their patterns and spatial distributions.

The second approach is, nevertheless, the less explored and usually applied in practice, despite some relevant good practice examples of mature spatial planning systems (i.e. Valencia's Law 5/2014 Spatial Planning, urbanism and landscape).

There is still great uncertainty in planning practice on how, and at which scales and phases of the planning process, it is feasible to make use of the NBS and ES approach. It can also be unclear how-to best benefit from the approach's integrative capacity for supporting sustainable development. From the perspective of practice, efforts have been also placed in understanding the interrelationships between urban infrastructures and the functions and services they provide, in order to: i) determine and anticipate the potential cascading effects and indirect impacts and malfunctioning when disruptions or risks occur (i.e. flooding, heat stress) and ii) identify when the complementary between green and grey solutions could be feasible and more beneficial.

In recent years, there has been an effort for undertaken modelling exercises for analysis of interdependencies between critical urban infrastructures and derived cascading effects due to infrastructure disruptions that affect the population and modify the needs for evacuation, medical care or rescue (water contamination, power disruption etc.). One of the most assessed impact chains has been water-related infrastructure, which can be considered as the immediate affected infrastructures under flood risk events. Below there are some examples of the most commonly analyzed flood related disruptions in the literature: 
- Transport disruptions due to flood-related accidents (derailment, collision of road vehicles, collision of maritime vehicles, structural elements collapse or overflow, e.g. tunnels, bridges, airports etc.);

- Transport disruptions due to large scale evacuation of civilian causing traffic congestion;

- Disruptions of water supply or contamination of drinking water or other health hazards;

- Hazardous substances incidents due to structural damages/flooding on facilities;

- Hazardous substances incidents due to accidents to transporting vehicles;

- Collapse of sewage systems;

- Electrical power supply disruptions;

- Telecommunications disruptions;

- Medical care facilities disruptions, due to power shortage, flooding, absence of drinking water, increased number of patients or inability of the personnel or supplies to reach the location;

- Industrial or business disruptions, due to power or communication disruptions.

\subsubsection{Complementarity green and grey for transition to new urban development}

Although NBS are related to many co-benefits (increase of biodiversity, $\mathrm{CO}_{2}$ storage, encourage physical activity, air pollution mitigation, etc.) on top of the functional infrastructure service they provide (sewage, transport, insulation, reduce temperature and UHI, shade provision), the realization of those benefits, however, is not necessarily straightforward.

Firstly, not all forms of green intervention are sustainable. Much is dependent on the nature of application and the extent to which the multiple benefits associated with ecology, society and economy can be achieved. Poorly thought maintenance regimes coupled with the use of mal-adaptation techniques (i.e. intensive requirements for soil and water) can lead to financial inefficiency. Trade-offs between desired benefits may also be sub-optimal (i.e. choices may have to be made whether to prioritize thermal stress alienation over and above say air quality).

Secondly, NBS provision may face a number of issues related to legitimacy. There may be approaches, for example, which fail to secure public acceptance and/or understanding. This is likely to be the case in situations where there has been limited opportunity for public involvement or opportunities for codesign have not been taken. Equally, limited knowledge, expertise or capacity amongst delivery actors may undermine the validity of approaches amongst key decision-makers makers. These may be further compounded by regulatory constraints and a cumbersome policy environment.

Thirdly, the nature of urban morphology presents its own challenges. In addition to the spatial constraints presented by the compact design of European cities, the complexity of the existing grey infrastructure (much of it underground) means that some solutions require a green or blue footprint which is unavailable. For instance, constructed wetlands offer useful solutions to dealing with wastewater, grey water and storm-water runoff but require a large surface area. As a result, interventions will often need to be considered which successfully integrate both green and grey infrastructure. The use of a complementary approach has been identified by scholars (Sturiale and 
Scuderi, 2019) as a pragmatic and effective means of accounting for morphological constraints whilst at the same time promoting urban sustainability.

The complementarity of both types of infrastructure, green and grey, allow to expand and complement the existing infrastructure with green features to cover the increasing need for the supply or demand of services. This issue has been frequently not fully addressed or covered in the practical implementation of NBS. As an example, you can see in the table below (Table 2.3.1) some green/grey solutions and their complementarities.

\begin{tabular}{|c|c|c|c|c|}
\hline Function & NBS & NBS Benefits & Constraints & Complementarities \\
\hline Water Treatment & $\begin{array}{l}\text { Constructed } \\
\text { Wetland (CW) } \\
\text { versus } \\
\text { Treatment } \\
\text { Plants }\end{array}$ & $\begin{array}{l}\text { Creation of natural } \\
\text { habitats, aesthetically } \\
\text { pleasant, promote } \\
\text { local wildlife, flood } \\
\text { control, recreational } \\
\text { and cultural activities, } \\
\text { educational, green } \\
\text { connection, and low } \\
\text { energy consumption. }\end{array}$ & $\begin{array}{l}\text { CW require a large } \\
\text { land area; false } \\
\text { design could result in } \\
\text { odor issues; lack of } \\
\text { widely accepted } \\
\text { design guidelines for } \\
\text { CW; optimal } \\
\text { performance is } \\
\text { reached after one or } \\
\text { two years of } \\
\text { operation. }\end{array}$ & $\begin{array}{l}\text { Both systems can be } \\
\text { working together. Part of } \\
\text { the water can be treated } \\
\text { in CWs, while another } \\
\text { part could be treated in } \\
\text { treatment plants. A } \\
\text { separate network for } \\
\text { pluvial and black waters } \\
\text { is encouraged. }\end{array}$ \\
\hline $\begin{array}{l}\text { Provision of } \\
\text { shade to cope } \\
\text { with Heat Stress }\end{array}$ & $\begin{array}{l}\text { Tree cover } \\
\text { versus artificial } \\
\text { shading } \\
\text { systems: } \\
\text { canopies and } \\
\text { pergolas }\end{array}$ & $\begin{array}{l}\text { Creation of natural } \\
\text { habitats, green view, } \\
\text { improve air quality, } \\
\mathrm{CO}^{2} \text { absorption, flood } \\
\text { control, etc. }\end{array}$ & $\begin{array}{l}\text { Trees and plants } \\
\text { need to be planted in } \\
\text { soil, which requires a } \\
\text { green and blue } \\
\text { footprint (land free } \\
\text { from underground } \\
\text { services) and they } \\
\text { also require } \\
\text { maintenance and } \\
\text { water irrigation. }\end{array}$ & $\begin{array}{l}\text { Very narrow streets } \\
\text { might not have space for } \\
\text { planting trees. In this } \\
\text { case, artificial shading } \\
\text { systems can be placed } \\
\text { and combined with } \\
\text { natural systems when } \\
\text { possible. }\end{array}$ \\
\hline Water runoff & $\begin{array}{l}\text { Sustainable } \\
\text { Urban Drainage } \\
\text { (SUDs) versus } \\
\text { Sewage system }\end{array}$ & $\begin{array}{l}\text { Aesthetically } \\
\text { pleasant, flood } \\
\text { control, can be linked } \\
\text { to recreational and } \\
\text { cultural activities, are } \\
\text { educational, allow for } \\
\text { a green connection, } \\
\text { decrease thermal } \\
\text { stress and UHI effect, } \\
\text { low energy } \\
\text { consumption. }\end{array}$ & $\begin{array}{l}\text { SUDs require a green } \\
\text { and blue footprint } \\
\text { (land free from } \\
\text { underground } \\
\text { services). They } \\
\text { require maintenance } \\
\text { and irrigation. There } \\
\text { are many types of } \\
\text { SUDs to prevent } \\
\text { from water runoff, } \\
\text { from detention } \\
\text { basins, to swales or }\end{array}$ & $\begin{array}{l}\text { SUDs are encouraged } \\
\text { wherever possible } \\
\text { combined with a } \\
\text { connection to the sewage } \\
\text { system in case of strong } \\
\text { storm events where the } \\
\text { SUDs solutions might } \\
\text { have not been planned. }\end{array}$ \\
\hline
\end{tabular}


NATURE-BASED SOLUTIONS FOR MORE SUSTAINABLE CITIES - A FRAMEWORK APPROACH FOR PLANNING AND EVALUATION

\begin{tabular}{|c|c|c|c|c|}
\hline & & & permeable paving. & \\
\hline $\begin{array}{l}\text { Air pollution } \\
\text { dispersion } \\
\text { solutions }\end{array}$ & $\begin{array}{l}\text { Vegetated } \\
\text { barriers versus } \\
\text { screens }\end{array}$ & $\begin{array}{l}\text { Air dispersion and } \\
\text { protection from } \\
\text { breathing pollutants. } \\
\text { At the same time, } \\
\text { they can be } \\
\text { aesthetically } \\
\text { pleasant, provide } \\
\text { flood control, allow } \\
\text { for a green } \\
\text { connection. They } \\
\text { provide also a } \\
\text { protection against } \\
\text { traffic, providing a } \\
\text { safe space for people. }\end{array}$ & $\begin{array}{l}\text { Vegetated barriers } \\
\text { require space free } \\
\text { from underground } \\
\text { services. They } \\
\text { require maintenance } \\
\text { and irrigation. }\end{array}$ & $\begin{array}{l}\text { Acoustic and air pollution } \\
\text { screens are less space } \\
\text { invasive, but they do not } \\
\text { provide environmental } \\
\text { benefits. Vegetated } \\
\text { barriers require more } \\
\text { space, but they can be } \\
\text { combined with green } \\
\text { areas. They can be } \\
\text { combined, depending on } \\
\text { the space constraints. }\end{array}$ \\
\hline $\begin{array}{l}\text { Transport } \\
\text { Infrastructure }\end{array}$ & $\begin{array}{l}\text { Green Corridor } \\
\text { versus } \\
\text { "concrete } \\
\text { corridor" }\end{array}$ & $\begin{array}{l}\text { Green ecological } \\
\text { connection, } \\
\text { aesthetically } \\
\text { pleasant, flood } \\
\text { control, can be linked } \\
\text { to leisure and } \\
\text { encourage physical } \\
\text { activity, social } \\
\text { connection, can } \\
\text { protect pedestrians } \\
\text { from harmful } \\
\text { pollution on open } \\
\text { roads if planted } \\
\text { strategically, shade of } \\
\text { tree canopies provide } \\
\text { protection from sun, } \\
\text { trees planted in close } \\
\text { proximity to each } \\
\text { other can reduce } \\
\text { both air pollution and } \\
\text { the urban heat island } \\
\text { effect. }\end{array}$ & $\begin{array}{l}\text { Green corridors } \\
\text { should be seen as an } \\
\text { essential element of } \\
\text { larger urban planning } \\
\text { as well as smaller } \\
\text { localized programs; } \\
\text { as they can provide } \\
\text { added benefits to } \\
\text { building, transport } \\
\text { and public realm } \\
\text { improvements. Large } \\
\text { city wide initiatives } \\
\text { together with } \\
\text { smaller plans, } \\
\text { complexity of } \\
\text { planning and space } \\
\text { needed are major } \\
\text { constraints. }\end{array}$ & $\begin{array}{l}\text { Accompanying with } \\
\text { green any type of lineal } \\
\text { infrastructure is a good } \\
\text { idea. The combination of } \\
\text { grey (concrete) and } \\
\text { green can go along, as } \\
\text { cars need a durable } \\
\text { surface and can be } \\
\text { complemented with } \\
\text { more functions with a } \\
\text { greener complementary } \\
\text { infrastructure. }\end{array}$ \\
\hline
\end{tabular}

Table 2.3.1 Comparation between some examples of green and grey solutions, their benefits, constraints and complementarities.

GrowGreen aims at contributing to the evidence base of Nature-based solutions (NBS) in cities for costeffective, replicable means of increasing urban climate and water resilience, social, environmental and economic benefits, to underpin the development of NBS policies and the global NBS market. Several interventions have been implemented in different countries that look for integrated solutions that 
improve several challenges: flood control, thermal stress, biodiversity, air quality, etc.The demonstration projects have proved that more benefits are encountered when working with NBS versus implementing pure grey solutions.

\section{GrowGreen Sustainable Pocket Forest in Valencia}

Objective and Challenges: The main challenges for the project were climate adaptation, water flooding and social enhancement.

Why Green Versus Grey?: Reducing thermal stress can be done by means of lowering the albedo of the surfaces and providing shade. This could have been done by using materials with a low albedo (white color, low radiation, etc.) and using pergola. This would have been a solution with a much higher cost, and less environmental and social benefits.

Solution: Sustainable forest with a topography to manage rainwater on site, include diverse plant species to provide biodiversity and green connection, and provide an accessible natural place near their homes where people can appreciate nature, provide relaxation, etc.

Main characteristics:

- The Sustainable Forest manages all water runoff on site without expanding existing infrastructure

- The NBS solution has been calculated to fulfill the requirement for all events except from extraordinary events every 500 years. In these extreme cases, there is a connection with the existing sewage to drain the excess water. Both infrastructures, green and grey, are interconnected and complemented.

- NBS features include infiltration basins connected in cascade by vegetated channels and permeable paving.

- Major co-benefits: water runoff management, water quality, increase biodiversity, improve urban quality, provide safe public space, provide equitable access to nature, $\mathrm{CO}^{2}$ absorption by selection of tree species, shade for sun protection, improve UHI effect.

GrowGreen West Gorton Community Park in Manchester

Objective and Challenges: The main challenge of Manchester's NBS demonstration project is flood protection. Besides it has been designed to deliver other benefits, including improving air and water quality, increasing biodiversity and enhancing community cohesion and active lifestyles.

Why Green Versus Grey? The city's long history of flooding is partly due to an ageing sewer system, culverted rivers and large areas of impermeable surface due to the city's growth. Surface water flooding has increased tenfold between 1945 and 2008, and is predicted to increase further with climate change.

Solution: The first park in the UK designed to 'drink water' Located in the neighborhood of West Gorton, and opened in June 2020, it is the culmination of a ten-year regeneration program for this area.

\section{Main characteristics:}

- The park includes meadow, woodland and community areas, and has been designed with local residents.

- The NBS design features in the park includes bioretention tree pits, swales, rain gardens, permeable paving and an irrigation rill.

- Existing trees were pruned to provide more attractive tree cover, framing the park and 
contributing to the water retention functionality of the park.

\section{GrowGreen: The New Green System - Wroclaw}

Objectives and Challenges: the main objectives of the project in Wroclaw are: increasing rainwater retention, biodiversity and the residents' accessibility to green spaces, in order to provide shelter from heat and a meeting place to build neighborly relations and social cohesion. Also improving air quality by increasing humidity (especially in summer) and reducing the concentration of suspended dust is one of the main project's goals.

Why Green Versus Grey?: In Wroclaw, the area covered by the project is one of the city's most densely populated districts with a very dense residential development, consisting mainly of centuryold tenement houses, with internal courtyards, mostly lacking greenery. This area suffers with poor air quality and - due to the predominance of impervious surfaces - severe urban heat island and local flooding (especially after heavy rains). Increasing the percentage of biologically active surfaces, i.e. natural, permeable surfaces covered with vegetation, ensures rainwater retention and increases air humidity thanks to evapotranspiration. NBS also improves air quality - vegetation filters the air from pollution (i.a. particulate matter), may act as a barrier to exhaust gases and noise, it also provides food and shelter for many species of animals. Introducing greenery into compact development allows to fight urban heat island. In addition, greenery helps to reduce the so-called urban stress (Tyrväinen et al., 2014) and provides space for social integration. The accompanying blue infrastructure, i.e. elements related to the presence of water, provides rainwater retention, contributes to increasing air humidity and also increases urban biodiversity.

Solution: The New Green System is a network of 7 pocket parks located in the courtyards between the buildings, and the Green Street - an area of the street adjacent to the yards. Together they form project demonstration areas where a range of NBS have been introduced.

Main characteristics:

- In the project demonstration areas, trees and shrubs were planted, low-growing / ground cover plants were also introduced (instead of lawns requiring excessive watering and care). In areas where planting trees and shrubs was not possible, vertical greenery has been introduced in the form of climbing plants;

- Blue infrastructure elements have been introduced, i.e. rain gardens (small hollows in the ground, planted with vegetation resistant to both periodic drought and flooding, also called bioretention facilities) and barrels collecting rainwater. Rainwater tanks allow to quickly drain some of the rainwater after rainfall, preventing local flooding, also collect water that can be used to watering plants during drought.

- Permeable surfaces have been introduced, i.a. in the form of a concrete grid that allows rainwater to infiltrate the ground;

- Animal houses and flower meadows (especially valuable for pollinators) have also been introduced in pocket parks. As required by the NBS definition, only natural, biodegradable and local materials were used.

- Plant beds where neighbors can grow plants together, a dog park and ecological playgrounds have been introduced, to provide spaces for social integration and ecological education;

- Along the Green Street, a row of trees has been planted, in order to improve air quality, provide shading and reduce the traffic noise. So-calles parklets have also been introduced - 
wooden constructions in the form of boxes in which trees and shrubs were planted and seating places were arranged. Parklets give the opportunity to take a rest in the shade, with a view of the greenery. Additionally, it is an element slowing the traffic along the street and thus reducing secondary remobilization of particulate matter (particulate matter uplift due to car traffic), minimizing smog.

Table 2.3.2: Projects description

\subsubsection{Knowledge gaps and opportunities for sustainable NBS}

Although a lot of progress regarding NBS and the demonstration of their benefits and sustainability assessment has been done in recent years, there are still significant knowledge gaps in understanding the long-term sustainability of NBS in comparison with established grey infrastructure approaches. New evidence is therefore required which can improve our understanding of the potential impact of NBS solutions in urban areas. In order that decision makers are able to target interventions towards the most critical parts of the infrastructure, an evidence-based approach to the assessment of alternative options and scenarios needs to be advanced. The current Horizon 2020 program provides a valuable initial response to this need. Through the provision of investment in NBS research and innovation, evidence is already emerging which highlights the extent of environmental change being experienced in urban areas and the contribution that can be made by NBS. Projects such as the NAIAD experiment have, for instance, indicated the different life cycle costs of green versus grey intervention, whilst the IGNITION study is beginning to gather evidence of the relationship between NBS benefits and investor confidence. GROWGREEN has applied different NBS in different cities to assess and demonstrate its sustainability versus grey infrastructures.

New pathways for NBS adaptation will also require substantial government commitment at the relevant administrative scale. Local governments therefore have a key role in the design of projects to help in the transformation of urban areas towards more sustainable solutions. Depending on the administrative structure in question, many authorities will have responsibilities, resources and capacity covering urban planning, water supply, sewage networks, wastewater treatment, highways, management of public open spaces, environmental protection and health. Despite this breadth of focus however, experience of urban greening has highlighted a tendency towards sectoralism and lack of integration between departments. In order to ensure a growth towards a more pluralistic approach, it is arguable that urban planning teams are well positioned to take the role of both enablers and conditioners of change. Not only do they have broad spatial understanding of the urban area in question, but they typically work at the interface of both the environment and the market and thus are able to explore new forms of 'green investment'.

The search for appropriate forms of NBS governance arrangements is further complicated by the unequal distribution of environmental impacts. Elderly populations along with those of marginalized social groupings have been found to be particularly vulnerable to changing urban environments. Urban strategies for sustainability and resilience therefore need to include both the provision of green solutions to existing city challenges (e.g. floods, heat stress, air quality, mobility issues, lack of access to nature.) as well as mechanisms for strengthening the local community. By perceiving environmental and community threats as inter-related rather than separate urban problems, we can plan for stronger and 
more resilient communities. In order to achieve this, communities need to be given active opportunities to co-produce the environmental futures of which they will be a part. The H2020 GROWGREEN project offers a useful example of how this might be achieved, by involving local communities through, and providing, important lessons for co-designed NBS. 


\section{References}

Directive 2014/52/EU of the European Parliament and of the Council of 16 April 2014

Enzi V., Cameron B, Dezsényi P., Gedge D., Mann G., Pitha U.: Nature-Based Solutions and Buildings The Power of Surfaces to Help Cities Adapt to Climate Change and to Deliver Biodiversity, from the book: Nature-based solutions to climate change adaptation in urban areas: Linkages between science, policy and practice, ISBN: 978-3-319-53750-4.

ESPON, 2019 GRETA BRIEFING 2 Relating Green Infrastructure to the Strategic Environmental Assessment, https://www.espon.eu/green-infrastructure

Feliu and Garcia (2020) IX CIOT. IX Congreso Internacional de Ordenación del Territorio. Proceedings Chapter 3.5. Adaptación al cambio climático en los instrumentos de ordenación del territorio y urbanismo hacia la resiliencia territorial: Experiencias en el País Vasco y Navarra. In press.

Lafortezza, R., Sanesi, G., 2019. Nature-based solutions: Settling the issue of sustainable urbanization. Environ. Res. 172, 394-398. https://doi.org/10.1016/i.envres.2018.12.063

Sturiale, L.; Scuderi, A. The Role of Green Infrastructures in Urban Planning for Climate Change Adaptation. Climate 2019, 7, 119.

The GrowGreen Project Compendium of nature-based and 'grey' solutions to address climate and waterrelated problems in European. Trinomics. March 2020 http://growgreenproject.eu/compendium-naturebased-grey-solutions/

Urban green spaces and health. Copenhagen: WHO Regional Office for Europe, 2016

Tyrväinen L., Ojala A., Korpela K., Lanki T., Tsunetsugu Y., Kagawa T.: The influence of urban green environments on stress relief measures, Journal of Environmental Psychology, vol. 38 (2014), p. 1-9. 